


\section{Online folyóirat}

Szerkesztette: VÁGÁNY Judit Bernadett, PhD - FENYVESI Éva, PhD

Borító: FLOW PR

Kiadja: Budapesti Gazdasági Egyetem, Kereskedelmi, Vendéglátóipari és Idegenforgalmi Kar, Közgazdasági és Üzleti Tudományok Tanszék

Felelős kiadó: FENYVESI Éva, PhD

a Közgazdasági és Üzleti Tudományok Tanszék vezetője

ISSN 2630-886X

2020. 


\title{
VÁLLALATI IMÁZS HATÁSA A MUNKAVÁLLALÓKRA
}

\section{IMPACT OF CORPORATE IMAGE ON EMPLOYEES}

\author{
BALOGHOVÁ Éva
}

Kulcsszavak: vállalat, vállalati imázs, munkavállaló, elkötelezettség, márka Keywords: company, corporate image, employee, commitment, brand

JEL kód: $M 30, M 31$ 


\section{ÖSSZEFOGLALÓ}

A kulcsszavak: büség, szeretet, rajongás. Egy szervezet képét állandóan formálják küilönbözó meghatározó tényezók, amelyek mindegyike hajlamos másfajta mércét alkalmazni ehhez. a folyamathoz: Az érdekelt felek mindegyike különbözó módon fogja megitélni ugyanazon szervezetet. Gondolunk itt arra az eshetöségre, mely során maga a cég alkalmazottja, a céghez árut beszerzó fél és a vállalattól vásárló kliens is másfajta képet épit fel magában a szóban forgó vállalatról. Ezen tanulmány viszont arra az egy meglévö helyzetre fókuszál s egyben azt a tényt próbálja megvizsgálni, milyen módon van hatással a vállalat alkalmazottjára a vállalati imázs.

Manapság a munkaeröpiac legnagyobb kibivásaként vehetjük a munkahelyi lojalitás bironyos szint feletti tartását, illetve a munkavállalói motiváció növelését. Temérdek megoldás létezik arra vonatkozóan, hogyan érhetünk el eredményeket ennek elösegitése érdekében. A téma bemutatása mellett kitérek arra is, bogy melyek azok a különféle dolgozói juttatások, amelyek segithetnek elérni kitürött céljainkat. A mai kor embereinek ismerös lehet ezen a téren is a kijelentés, hogy nehezebb megtartani, mint megszerezni. Azélet néha keveset ad, de gyakran elvesz - igy van ez legtöbbször a munkavállalók eltávozásával is egy bizonyos vállalattól.

Munkám fó célja bemutatni a téma elméleti hátterét, mivel úgy gondolom, manapság a vállalatok nagy része van kitéve ennek a problémának. Azidö szükössége miatt egy komplex, nagy volumenü kutatásra nem került sor, ennek ellenére a munka tartalmaz ötleteket, tanácsokat, milyen módon szerez̧hetö vissza avagy nyerhetö meg újonnan a munkavállaló belénk fektetett bizalma, hogyan lesz. elkötelezett viszonya a vállalatunkekal. Vállalatok mindennapjainak meghatározó részeivé váltak a munkavállalók, amely kapcsolathoz elengedhetetlen megteremteni számukra a bizalmi légkört, ezért tartottam fontosnak ezt a témát megvizsgálni.

\section{SUMMARY}

The keywords are loyalty, love, enthusiasm. The image of an organization is constantly shaped by various determinants, each of which tends to apply a different standard to this process. Each of the stakeholders will judge the same organization in different ways. We are thinking here of the possibility that the company itself, the party buying the goods for the company, and the client buying the company will also create a different image of the company. However, this study focuses on the existing situation and tries to examine the impact of corporate image on the company's employees.

Nowadays, one of the biggest challenges in the labor market is to keep work loyalty above a certain level and to increase employee motivation. There are a lot of ways to achieve results in order to facilitate this. In addition to presenting the topic, we also discuss the various employee benefits that can help us achieve our goals. Today's people may be familiar with the statement that it is harder to keep than to obtain. Life sometimes gives little, but often takes away what it wants - this is most often the case with employees leaving a certain company.

The main purpose of my work is to present the theoretical background of the topic, because I think most of the companies today are exposed to this problem. Due to the time constraints, no complex, large-scale research has been carried out, however, the work contains ideas, advice, how to gain the trust of the employee in us, how will it be committed to our company. Employees have become a crucial part of the 
everyday lives of companies, and it is essential to create a climate of trust for them, so I thought it was important to look at this topic.

\section{Imázs vagy vállalati arculat?}

A marketinggel foglalkozó ember eszköztárában szereplő egyik népszerű eszköz a „vállalati imázs” fogalma. A koncepció azon a felismerésen alapul, hogy az ügyfelek márkás termékeket vásárolnak nemcsak jellegzetes tulajdonságaik miatt, hanem azért is, mert a kiválasztott gyártók termékei iránti elfogultság és hajlandóság mutatkozik. Manapság fontos tényezőnek számít egy vállalatról alkotott kép, hiszen mind a szervezet számára, mind az érdekelt felek számára meghatározó lehet. Nagyban befolyásolják a piaci tranzakciókat, a piaci pozíciót. Ezért is fontos rövid betekintést tennünk e téma irányába.

A két fogalom napjainkban a leggyakoribb kifejezések közé tartoznak a médiában. Azonban egyre jobban észrevehető a vállalatvezetők részéről, hogy ők bizony keverik ezen fogalmakat és nincsenek tisztában jelentésükkel. (Wallin, 1998)

Az arculat nem más, mint a vállalat megjelenési formáinak összessége. Kirakósként képzelhető el az egész; a kirakós darabkái az arculati elemek, végül a kirakott kép pedig maga az egységes arculat - minden olyan tényező, amit a cég mutat magáról. Akkor tökéletesíthető a mű, ha a kirakós egyes darabkái egymáshoz passzolnak. Felsorolhatók ide névjegyek, levélpapírok, szórólapok, plakátok. (Corporate Image, 2015)

Egy másik megfogalmazás szerint a vállalati arculat egy cég befelé és kifelé irányuló önábrázolását és magatartását jelenti, ezen felül egyes megnyilvánulásainak megtervezett, tudatosan és folyamatosan igénybe vett összességét értjük. A vállalati magatartás, a vállalati megjelenés és a kommunikáció egyik jeles jelentőségű kombinációja, amelyben megjelenik egyúttal a vállalat személyisége és saját magáról alkotott és közölni kívánt képe. A vállalati arculattal egyetemben azonosítjuk magát a vállalatot és megkülönböztetjük őt másoktól. Minősítjük, ezen felül egy gazdaságos tényező is, emellett a szolgáltatás minőségét is képesek vagyunk vele meghatározni.

Az imázs ellentétben a megfoghatósággal inkább egy belső kép, ami a vevő és az alkalmazott fejében létrejön magáról a vállalatról, a márkáról esetleg a termékről. Kialakulását sok tényező befolyásolhatja; egyrészt az az arculat, amelyben megjelenik a vállalat a piacon, másrészt pedig minden olyan tényező ide tartozik, amit a vállalattal kapcsolatban hallunk, látunk, olvasunk.

A vállalati imázs ezen felül tükrözi az ügyfelek egy szervezettel kapcsolatos felfogását, amely az adott társasággal kapcsolatos tapasztalatok vagy benyomások eredményeként jönnek létre. A szolgáltatási szakirodalomban is széles körben elismerték a vállalati imázst, mint értékes eszközt, amelyet a cégeknek kezelniük kell a szervezet általános értékelésének kialakításához. (Mostafa et al., 2015)

A fogalmat meghatározva így elmondható, hogy míg az arculat a vállalat külső megjelenése, addig az imázs belső megítélés alapján jön létre, amit a vevők gondolnak a cégről. 
Mindkettő könnyen kialakítható, fejleszthető terület, ami végül a cég javát fogja szolgálni. (Mi a különbség az imázs és az arculat között? (Riordan, 2014)

A mai versenyképes piacokon az ugyanazon iparágon belüli szolgáltatások és szolgáltató vállalatok egyre inkább hasonlóak. Nehéz megkülönböztetni a szállítási csatornát. Egyre több szolgáltató vállalkozás kezd el pozícionálni a kommunikációs csatornán keresztül (azaz a reklám és a személyes értékesítés) azzal a céllal, hogy erôs vállalati imázsokat hozzon létre a relatív vonzerô megteremtése érdekében. (Andreassen, 1997)

\section{Munkavállalói elkötelezettség}

Hasznos dologként vetíthetjük fel az elköteleződést, hiszen minden ismert teljesítménymutatóra hatással van. A munkahelyi elköteleződés az egyik olyan tényező, amiből soha nem elég. Temérdek vezetői és humán erőforrás szakember tudja, hogy az elköteleződés fontos dolog, ám sokszor tanácstalanok afelől, hogy miként lehet ezt felébreszteni munkavállalóiban. Szinte az összes teljesítmény mutatóval korrelál, egészen a munkahelyi hiányzásoktól a selejtes termékek számán át az ügyfelek értékeléséig.

Világossá vált mára, hogy a vállalatok nagy többsége hatalmas összegeket képes fordítani az elköteleződés növelésére. (Corporate Image, 2015)

Egy 2014-ben, a Towers Watson által publikált Globális Munkaerő Kutatás megmutatja, melyek azok a kihívások, amelyekkel manapság a szervezeteknek foglalkozniuk kell. A kutatás nemcsak egy bizonyos régiót fedett le, hanem 26 ország 32000 válaszadóját szólította fel véleményének kinyilvánítására. (Employee engagement, 2013)

A kutatás a kihívások mellett kitér arra is, hogy milyen formájú munkát vállalnak az egyes kitöltők, míg egy másik kérdés azt taglalja, mely készségekre lesz a legnagyobb szükség a jövőben. A válaszadók kevesebb, mint fele jelezte, hogy távmunkában vagy rugalmas munkaidőben dolgozik, míg a készségeket tekintve a virtuális kommunikáció, a jövőközpontú gondolkodás és a digitális készségek lesznek szükségesek a múködéshez a jövőben.

Viszont a kutatás jobbára azt a tényt vizsgálta, hogy milyen szintű a dolgozók elköteleződése és milyen módon lehet ezt növelni a mai 21. században. Kutatásuk során kialakítottak egy teljesen új fogalmat, méghozzá a fenntartható elköteleződést. Azért is nevezhető újszerűnek, mivel eddig az elköteleződést úgy állapítottuk meg, hogy a munkavállaló erőfeszítéseket tesz azért, hogy a vállalat elérje kitűzött szervezeti céljait. Az új megközelítés szerint még két tényezőnek kell jelen lennie a fenntarthatósághoz, méghozzá: a szervezeti támogatottság érzésének és az egyéni jóllét érzésének.

Ezen 3 elem - erőfeszítés, támogatottság érzése és energizáltság érzése - megléte avagy hiánya alapján 4 csoportba oszthatjuk a munkavállalókat az elköteleződésük által:

1. Teljes mértékben elégedett - mindegyik elem jelenlétének értéke magas,

2. Nem támogatott - alacsony szinten jelenik meg a támogatottság és az energizáltság,

3. Kiábrándult - mindegyik elem értéke nagyon alacsony, 
4. Motiválatlan - az erőfeszítés mértéke alacsonynak mutatkozik.

Végül pedig egy olyan témát tárgyal a kutatás, amely sorsdöntő lehet a munkavállalói elköteleződés kialakítása során. Kíváncsiak voltak arra, melyek azok a tényezők, amelyek befolyásolják az értékeket. Öt olyan tényezőt tudtak lapra vetni, amelyek talán a legerősebb hatással vannak a munkavállalói elköteleződésre.

Az öt meghatározó tényező:

1. Felhatalmazás - ez alapján azt figyelik, mennyire vonja be a vezetés a dolgozókat a döntéseikbe, és milyen mértékben veszik figyelembe egyéni javaslataikat

2. Célkitűzések - értik maguk a dolgozók is a kitűzött célokat, és látják, milyen módon járulnak hozzá elérésükhöz,

3. Vezetés minősége - jellemző rá a hatékony, következetes és bizalomébresztő viselkedés, emellett figyelembe veszi a munkavállaló jóllétét,

4. Munkaterhelés és munka-magánélet egyensúly - elég munkavállaló van jelen adott munka elvégzésére, rugalmasság a munkavégzés során, elfogadható és kezelhető munkaterhelés,

5. Vállalati image - jobbára etikus vállalati viselkedést jelent, a környezet szemében a cég jó hírnevének és tiszteletnek örvend.

Persze ezek nem a mindennapok során alkalmazott jutalmazásközpontú elemek, amelyek a munkavállalók vonzását és azok megtartását biztosítják, hanem olyan elemek, melyek jobbára a cégkultúrára és a kapcsolati elemekre vonatkoznak. Fontos megemlíteni, hogy ezek között az elemek között olyanokat lelhetünk fel, amelyek nagymértékben a cégek vezetőin múlnak, mennyire érik el velük munkavállalóik elköteleződési szintjét. (Kriston, 2018), (Így lesz elkötelezett a dolgozó, 2016)

\section{A munkáltatói márkázás}

A munkáltatói márkázás a szervezetiidentitás-mix egyik részterülete, amelyet talán úgy értelmezhetnénk legpontosabban, mint a munkavállalók felé történő információ átadás lényeges elemeként az identitás meghatározása szempontjából. A munkavállalókkal való együttműködés szabályainak pontos meghatározása, melyek munkáltatói márkázásnak (employer branding) is említhetünk, tartalmazza a szervezet törekvéseinek összességét a jelenlegi és jövőbeni alkalmazottak felé annak kommunikálására, hogy az adott munkahely megfelel az elvásároknak.

A munkáltatói márkázás alapjában véve funkcionális, gazdasági és pszichológiai előnyöket tartalmaz, amelyet a szervezet, mint a munkaadó bocsát ki és olyan jegyeket tartalmaz, mely által az alkalmazott beazonosíthatja a szervezetet. Sikeressége ennek a folyamatnak abban rejlik, hogy a szóban forgó vállalat mennyire tudja megteremteni azt az érzetet, hogy fogyasztói és munkavállalói márkája összehangoltságot képeznek, és ezt milyen módon tudja elsajátítani a hosszú és rövid távú stratégiája során. (Dörnyei, 2014) 


\section{Employer Branding - mi is ez pontosan?}

Napról-napra feltörő ágazatként jelenik meg a HR szakmában ez a marketinggel összekapcsolható folyamat, melyet munkáltatói márkaépítésnek is nevezhetünk. Mint ahogy azt egy márka esetében, itt is a megfelelő arculat és imázs kialakítását kell célba venni, melyhez természetesen a marketing eszköztár számos lehetőséget és segítséget vetít fel számunkra. Egy olyan képet kell kialakítani ezáltal a potenciális munkavállalónak a cégről, amely pozitív irányba befolyásolja mindennapi tevékenységüket és hangulatukat egyaránt: a folyamat során fel kell tárni a pozitívumokat, miért jó ott dolgozni az adott vállalatnál, ezzel ellentétben meg kell találni azokat a negatív pontokat, amelyek javításra szorulnak a nagyobb megelégedés elérése érdekében. Az employer brandingre tehát tekintsünk úgy, mint gyökeres probléma kezelésre és a soron következő lehetőségek feltárására. (Panyi, 2018)

Nézzünk csak egy általános példát rá: gondoljunk csak a porszívókat áruló, házaló, folyton úton levő ügynökre. Ha mi magunk is egy ügynökség vagyunk, kérdezzük meg őt, hogy érzi magát pozíciójában. A márkaépítés ilyenkor lép életbe, amint elkezdünk beszélgetni beosztottunkkal arról, mi is a különbség az észlelt és a feltételezett pozíció között, hogyan értékelik saját munkájukat, mivel elégedettek, min változtatnának. Az erre a kérdéskörre kapott válaszok mélyen tükrözik vállalatunk arculatát, amelyet a munkavállaló alakított ki rólunk. Ezt követően ezen gondolatok helyrerakása és javítása a fejekben sokkal produktívabb lehet, hiszen a tudatalatti érzetek járulnak hozzá mindennapjaink jó vagy rossz közérzetéhez. Ez a fajta átpozícionálás segíthet a fluktuáció csökkenésében és akár munkatársaink hosszútávú megtartásában is. Érdemes rászánnunk az időnket kollégáinkra, ha hosszú távra tervezünk velük együttműködni. Hiszen sikert csak úgy érhetünk el, ha együtt tudunk múködni. (Panyi, 2018)

\section{Nehezebb megtartani, mint megszerezni}

Valószínúleg már sokszor hallottuk elhangzani ezt a mondatot. Az élet szinte bármely területén találkozhattunk már vele, akár tanároktól, orvosoktól, sikerorientált vállalati vezetőktől, de még párkapcsolati tanácsadóktól is hallhattuk.

Legjobban talán vállalatvezetők érzik ennek a mondatnak legjobban a súlyát, hiszen biztosan volt már olyan alkalom, amikor komoly szaktekintélyek, ígéretes tudással rendelkező fiatalok távoztak az adott vállalattól, csupán azért, hogy másutt számukra jobb munkakörnyezetet fognak kialakítani vagy nagyobb elismerést kapnak. Ezért is gondolhatjuk jogosan, hogy a munkahelyi lojalitás növelésében az elismerés kritikus pontot jelenthet.

Ahogy azt az előzőekben már bemutattam, a munkahelyi lojalitás, az elköteleződés gyakorlatilag minden teljesítménymutatóra lényeges hatást fejt ki. Rengeteg cégvezető és HR munkatárs van azon a véleményen, hogy a munkahelyi lojalitás növeli a vállalat gazdasági hatékonyságát és csökkentheti a fluktuációt. Azonban még mindig észrevehető egyes vállalatvezetőknél, hogy kevésbé szentelnek időt az adott problémára, mondván, régebben sem számított az, mennyire érzi jól magát a munkahelyén a munkavállaló. 
Abban az időben viszont még nem volt ekkora munkaerőhiány megfelelő szakemberekből, ahogyan a dolgozói énmárka sem volt ennyire lényeges. (Lojális munkavállalók, 2018)

\section{Egyiptomi telefonos hálózatok}

Egyiptom kulturális és politikai szempontból vezető ország a Közel-Keleten. Kulturális szempontból központi szerepet képvisel a Közel-Kelet Hollywoodjaként, inspiráló filmiparával. Politikai szempontból talán az egyik legmeghatározóbb forradalom 2011 ben zajlott, amikor is több millióan gyűltek össze Kairó Tahrir nevezetű terén, hogy az ország elnökének lemondását segítsék elő. Ezalatt a forradalom alatt az egyiptomi telekommunikációs ipar játszott kulcsszerepet, mivel a mobiltelefon-technológia és az online közösségi hálózati szolgáltatások az egyik fő eszköz, amelyet az egyiptomiak az országban elterjedt összejövetelek és demonstrációk megszervezésére használtak. Mivel a hatékony szolgáltatás-helyreállítási folyamat központi szerepet játszik az ügyfelek elégedettségének és más marketing eredmények elősegítésében, egyre növekszik az igény az egyiptomi szolgáltató vezetők számára, hogy érzékenyek legyenek a vásárlók igényeire és panaszaira. Az egyiptomi kutatás 6 hónap alatt készült el, 29 mobiltelefon-hálózati szolgáltatójukhoz panaszos ügyfelek által, s így betekintést nyertek a szolgáltatás helyreállítási folyamatának és a vállalati imázs kapcsolatának jellegéről. A válaszadóknak lehetőségük nyílt arra, hogy elmondják, mennyire voltak elégedettek az adott szolgáltatással. Hipotéziseket állítottak fel a kutatás során, melyből az szűrődött le végül, hogy az interakcionális igazságosság pozitív hatással van a vállalati imázsra, ennek ellenére az elosztó és az eljárásbeli igazságosságot a vállalati imázshoz összekötő két út azonban nem jelentéktelen. Az viszont tény, ha a szolgáltató valamit megjavít, pozitívan befolyásolja a vállalati imázst, ami megerôsíti a kapcsolat rendkívül korlátozott kutatását. Kiderült még emellett, hogy míg az interaktív igazságszolgáltatás közvetlen hatása a vállalati imázsra pozitív, addig a disztribúciós igazságszolgáltatás és az eljárási igazságszolgáltatás közvetlen hatása a vállalati imázsra nem szignifikáns. A disztribúciós igazságszolgáltatásnak a vállalati imázsra gyakorolt közvetett hatása - a szolgáltatáshelyreállással való elégedettség révén - pozitív. Ez a közvetett hatás erősíti a teljes hatást a közvetlen hatás hiánya ellenére. Az eljárási igazságszolgáltatásnak a vállalati imázsra gyakorolt közvetett hatása - a szolgáltatás helyreállításával való elégedettség révén pozitív. A teljes hatás szintén pozitív annak ellenére, hogy nincs közvetlen hatása. Végül, az interaktív igazságszolgáltatásnak a vállalati imázsra gyakorolt közvetett hatása - a szolgáltatás-helyreállítással való elégedettség révén - pozitív.

A fent említett eredmények azt mutatják, hogy az interaktív igazságszolgáltatásnak a vállalati imázsra gyakorolt közvetlen hatása mellett a három észlelt igazságszolgáltatás közvetett módon befolyásolja a vállalati imázst is a szolgáltatás-helyreállással való elégedettség révén. Noha a szolgáltatás helyreállításával való elégedettség teljes mértékben közvetíti mind a disztribúciós, mind az eljárási igazságszolgáltatásnak a 
vállalati imázsra gyakorolt hatásait, részben közvetíti az interaktív igazságszolgáltatásnak a vállalati imázsra gyakorolt hatását.

\section{FELHASZNÁLT IRODALOM}

DÖRNYEI,K. - BAUER,A. (2014) A szervezeti identitás meghatározása, elemei és menedzselése. Vezetéstudomány XLV.ÉVF. 5.szám, ISSN: 0133-0179 1-6.old.

HUFFINGTONPOST. (2015) Corporate Image: The Critical Foundation of Your Brand. , 2015, [online], interneten elérhető: https://www.huffingtonpost.com/ira-kalb/corporate-image-thecriti_b_8096582.html

HUFFINGTONPOST. (2013) Employee engagement: How are your employees affecting your brand? 2013, [online], interneten elérhető: https://www.huffingtonpost.com/marilyn-nagel/employeeengagement_b_3956204.html

PÉNZÜGYEINK BIZTONSÁGBAN. (2018) Lojális munkavállalók, avagy hogyan tartsd meg a legjobb munkatársaid dolgozói juttatások segitségével. 2018, [online], interneten elérhető: https://penzugyeinkbiztonsagban.hu/vallalkozoknak/lojalis-munkavallalok-avagy-hogyantartsd-meg-a-legjobb-munkatarsaid-dolgozoi-juttatasok-segitsegevel/90

PIAC\&PROFIT. (2016). Így lesz elkötelezett a dolgozó. 2016, [online], interneten elérhető: https://piacesprofit.hu/kkv cegblog/igy-lesz-elkotelezett-a-dolgozo/

PIAC\&PROFIT. (2013) Mi a különbség az imázs és az arculat között?. 2013, [online], interneten elérhető: https:// piacesprofit.hu/kkv cegblog/mi-a-kulonbseg-az-imazs-es-az-arculat-kozott/

PIAC\&PROFIT. (2018). Az elégedett ïgyfél is elcsábitható. 2018, [online], interneten elérhető: https://piacesprofit.hu/kkv cegblog/az-elegedett-ugyfel-is-elcsabithato/

RANIA,M. Et al. Corporate Image: A Service Recovery Perspective. In Journal of Service Research. 2015. https://doi.org/10.1177/1094670515584146

RIORDAN,CH. - GATEWOOD,R. - BARNES,J. (2014) Corporate Image: Employee Reactions and Implications for Managing Corporate Social Performance. Springer. Vol.16, No.4. In Journal of Business Ethics. 401-412.o.

WALLIN, A. Customer loyalty and complex services: The impact of corporate image on quality, customer satisfaction and loyalty for customer with varying degrees of service expertise. In International Journal of Service Industry Management. Vol. 9 No.1. 1998. pp. 7-23. https://doi.org/10.1108/09564239810199923

WALLIN, A. The Effect of Corporate Image in the Formation of Customer Loyalty. In Journal of Service Research. 1998. https://doi.org/10.1177/109467059800100107 
${ }^{18}$ 这 57
BGE 